thought the whole sequence indicated a progressive warming and desiccation of the climate, though interrupted by seasonal torrential rains. At several stages no plants are known, but their presence is indicated by herbivorous reptiles, and the appearance of Crustacea characteristic of the European Carboniferous may indicate considerable warmth in the later stages.

In the discussion (which proved to have needed more time than was allotted) many observations were made. Dr. Chesters confirmed the existence of mangroves in the English Eocene and also stated that epiphytes had still not been found. There were apparently opposed statements about the rate of decay of plant remains in tropical muds which called for a series of experiments to find out the truth. One of the Upper Karoo plants (Lepidopteris stormber. gensis) was compared with a modern waterside aquatic herb, with which it agrees in that some small leaves, presumed to be lower ones, have more numerous stomata above than below. Its other leaves are normal. Others pointed out that lime. stones are forming to-day in East African lakes quite apart from evaporation of the water.

Dr. Hamshaw Thomas ended the discussion fittingly by suggesting that the early floras, like none on earth, grew in climates like none on earth to-day, but just how these climates differed he left us to ponder.
TOM M. HARRIS

\title{
WEATHER MODIFICATION IN THE UNITED STATES
}

$\mathrm{T}$ HE National Science Foundation has recently initiated a programme in which $1,130,000$ dollars will be distributed in thirteen grants for laboratory research, field experiments and conferences on meteorological methods directed toward modification of weather. The programme aims at an intensive study of the scientific basis of weather control, through the support of scientists working in cloud physics and allied fields.

Seven of the grants will make extensive use of experiments in the field to study the formation and characteristics of clouds, and possible changes in clouds induced by man.

Horace R. Byers and Rosene R. Braham of the Department of Meteorology, University of Chicago, have received a grant of 114,300 dollars for a study of the physical effects of silver iodide seeding over the Great Plains. Cloud seeding in mountainous areas of the Pacific coast appears to result in measurable increases in precipitation. Over the flat terrain of the Great Plains, however, positive results have not been shown. This project will therefore release silver iodide nuclei from aircraft and investigate the resultant physical changes in the clouds themselves, rather than attempt to measure statistical departures in precipitation.

A. Richard Kassander, Louis J. Battan, and James E. McDonald of the Institute of Atmospheric Physics, University of Arizona, have received a grant of 161,800 dollars to study the physies of clouds and of cloud modification. In recent cloud-soeding experiments it was discovered that mean rainfall was approximately 30 per cent higher on seeded than on non-seeded days, and lightning flashes were about nine times more numerous on seeded days. These investigations will continue in an attempt to improve knowledge of the development of clouds, precipitation and electrification.

Robert D. Elliott of Aeromotric Research, Inc., Goleta, California, will conduct an investigation of precipitation processes and efficiency of Pacific coast storms with a grant of 90,500 dollars. Statistical data on west coast storms are already available from the Statistical Laboratory of the University of California at Berkeley, and elsewhere. An intensive effort will now be made to obtain physical data on west coast storms, including water content, nuclei number, potential gradient, and standard meteorological parameters. This will then be combined with the statistical data to develop, it is hoped, a complete model of a west coast storm.

Dwight B. Kline of the United States Weather Bureau, Department of Commerce, will direct an 18-month programme with a grant of 68,900 dollars, on synoptic observations and studies of freezing nuclei anomalies. It has boen observed that about 30 days after known meteor showers on the Earth, a peak is reached in the number of freezing nuclei in clouds, in widely separated geographical locations. Other apparent coincidences between meteor showers and freezing nuclei have been noted. The U.S. Weather Bureau will conduct a systematic collection of results on freezing nuclei taken at widely scattered places at the same time. It is hoped that definitive information on the effects of meteoric dust on cloud nuclei can be obtained from this study.

The Atmospheric Research Group of Pasadena, California, will receive a 57,100 dollar grant to conduct field studies in cloud physics related to nucleation, hydrometeor development, electrification, and cloud dynamics. Field studies of small, 'simple' clouds will be conducted to investigate the effects of time, temperature, humidity, and drop-size on nucleation. Cloud seeding will be used as a research tool, most of the field measurements being carried on in the region of Flagstaff, Arizona.

The National Science Foundation has transferred 50,000 dollars to the Office of Naval Research in support of cloud electrification studies by A. D. Little, Inc., under the direction of Bernard Vonnegut. This work involves studies of the precipitation process and the processes at work in the electrification of thunderstorms.

Meteorology Research, Inc., will receive, subject to satisfactory completion of negotiations, a 40,000 dollar contract for two-year cloud-physics studies at Santa Barbara, under the direction of Paul MacCready, using radar to describe individual storms in great detail, to determine differences between storms, and formulate hypotheses on the relative seedability of various storms.

A laboratory project will be carried out in the Department of Meteorology of the University of Chicago, where Horace R. Byers has received a threeyear grant of 383,700 dollars for research in cloud physics, covering the factors believed to be important in precipitation mechanisms: particles and nuclei, ice nucleation processes, and the growth of ice crystals and water droplets. 
Two grants have been made for statistical evaluation of eloud-seeding experiments. J. Neyman of the University of California at Berkeley will direct a group in the Statistical Laboratory on randomized cloud-seeding experiment under a two-year grant of 64,900 dollars. Such experiments have been conducted for two years in Santa Barbara and Ventura counties, and will be continued. The data available will be subjected to statistical scrutiny independent of any a priori hypotheses concerning the distribution of rainfall, using non-parametric statistical methods with the aid of a high-speed computer.

Max A. Woodbury of the Department of Mathematics, New York University, will make a two-year study of the statistical evaluation of weather modification with a grant of 58,800 dollars.

Three grants in support of conferences have also been made. The American Geophysical Union has received 25,000 dollars for a conference on "Mechanisms of Precipitation Formation". The National Academy of Sciences-National Research Council has received 10,000 dollars for a conference on the "Design and Conduct of Research Programmes in Weather Modification", under the direction of S. S. Wilks of the Division of Mathematics. The Foundation for Instrumentation Education and Research received 5,100 dollars for a conference on "Instrumentation for Cloud and Weather Modification".

\section{PERSONNEL MANAGEMENT IN PERSPECTIVE}

$\mathrm{A}^{\mathrm{N}}$ $\mathrm{N}$ inquiry into the reasons why modern personnel management is experiencing a crisis in its development, and why it is not producing better work through happier employees, has recently been made by Col. L. Urwick*. The major weakness in modern personnel management is, he suggests, its lack of integration into the organizational structure of businesses. There are many historical reasons for this trend and it needs urgent remedying. The corrective needs to be introduced at the very top of industry, by the leaders of business themselves.

The final strength of a business is no more than the collective strength of the individuals composing it. This has been known for years and in the past two decades business has invested millions of pounds in various schemes of personnel management. The expected results have not been achieved. The workforce remains obstinately unmoved, and management itself has its doubts. One reason is that business still looks on its employees as 'economic men' seeking exclusively economic objectives, whereas in reality social objectives are more important to most employees. Another reason is that employees are seen as individuals and not as members of a social group. The effort of personnel management is not directed towards achieving high morale through the social group. The test of a good personnel policy is high

* Institute of Personnel Management. Occasional Papers, No. 13 : Personnel Management in Perspective-Suggestions on the Correct Place of Personnel Activities in Business Organization. By L. Urwick.
Pp. 23. (London: Institute of Personnel Management, 1959.) 4s. morale, a matter not so much of doing things materially for employees, as of stimulating them to achieve something together. High morale requires, above all, leadership from the chief of the enterprise.

Historical trends have weakened the leadership content in personnel management. Personnel activities have become something 'tacked on to' a business because of the need for specialization, and this has prevented the personnel officer from obtaining the authority which should have accompanied his specialized responsibility. The solution is to make the 'line' manager at every level more directly responsible for personnel activities, using the personnel officer more fully for advice.

'Line' managers, especially at the heads of businesses, have found themselves overloaded in attempting to discharge their personnel responsibilities. The solution is to develop the use of general staff officers who can relieve their chiefs of details in all their functions. The possibilities here have long been understood by the Armed Services but are still not exploited in business.

Personnel management has suffered from the growing pains of the new kind of management, which acknowledges a much greater social responsibility, but is fitful in its efforts to shoulder the new burdens. Personnel men were given sometimes too much authority, sometimes too little. The solution is patient, sustained and prudent effort over many years by business leaders to get a personnel policy working well within their organization.

\section{HAMATOLOGY}

\begin{abstract}
A NUMBER of the British Medical Bulletin (15, No. 1 ; 1959) has attempted to review some of the many important advances that have been made in hrmatology in the past few years. This, in a series of fourteen articles, the contributors have done in a most stimulating and readable manner. The subject-matter covered includes the deficiency anæmias, the chemistry of normal and abnormal hæmoglobins and their inheritance, hæmolytic anæmias, the leukæmias, the life-history of the lymphocytes and bone marrow culture.

Many of these reviews are particularly stimulating. The description of the life-history of the lymphocytes, cells which hitherto have been somewhat mysterious cells, shows that the usual concepts of their life within the body must be reconsidered.
\end{abstract}

Normal hæmoglobin synthesis is presented in contrast to a description of the chemistry of the abnormal hæmoglobins. Modern methods of electrophoresis and chromatography have shown that the sole difference between normal adult and sickle-cell hremoglobin lies in the substitution of one aminoacid for another in one of their constituent peptides. Similarly, the exact defects in other abnormal hæmoglobins are being elucidated.

The alterations of red cell structure in other forms of hæmolytic anæmias are described where (either due to inherited or acquired defects) chemical changes in the lipoid, protein, glutathione or glycolytic systems can be demonstrated. Other aspects of the hæmolytic mechanisms are covered by reviews of the latest modifications in our knowledge of the 